\title{
Urban Alienation in Wong Kar Wai's Films
}

\author{
By Ethel Chong \\ Spring 2003 Issue of KINEMA
}

\section{IN THE MOOD FOR LOVE: URBAN ALIENATION IN WONG KAR WAI'S FILMS}

They say that love can change a man. I start to find myself looking better and more charming, and suddenly I discover that I'm turning blonde. (Qiwu in Fallen Angels)

The four films which I am going to discuss are Days of Being Wild (1991), Chungking Express (1994), Fallen Angels (1995), and Happy Together (1997). These four films were directed by Hong Kong director, Wong Kar Wai, who wowed the critics at Cannes 2000 with In the Mood for Love (2000). Wong has been hailed as the definitive Hong Kong arthouse director. His postmodern themes and filming techniques focus mainly on the anxiety within modern urban living. His films do not provide an answer to the anxiety, nor tell the audience how to deal with the anxiety. In a nutshell, Wong's films are about our postmodern human condition.

Wong's characters are very much alone in the large city environment. They are alienated from one another even though they are involved in one another's lives. There is an underlying sense of dystopia and confusion. The city is too big and life moves too fast to give each individual character space. Each character cries out to be heard. The characters want to love and be loved, and yet are so dysfunctional that they cannot do so. The urban environment forces the characters to blend in en-masse, so that individuality is forfeited. Each character has to play by the city's rules, in order to survive day by day. The meaning of love hence becomes distorted and lost.

At this juncture, I would like to give a brief synopsis of each of the films chosen. In Days of Being Wild, Yuddy, the protagonist, is an unemployed young man living in Hong Kong in the 60s. He has fleeting relationships with two women, Su Lizhen (a drinks seller) and Mimi (a dancer). Yuddy cannot commit to a relationship as he has been abandoned by his biological mother and thus rejects all notions of family life, likening himself to a bird which is constantly flying. Tide is a policeman/sailor who falls in love with Su Lizhen. Zeb, Yuddy's friend, falls in love with Mimi, but alas, both women pine only for Yuddy, even though they are rejected.

In Chungking Express, Wong weaves a tale of two policemen, Cop 223 and Cop 663, who are both rejected by their girlfriends. Cop 223 is dumped by a woman named May, who loves to eat pineapples. In a bid to forget her, he eats thirty cans of pineapples and then goes drinking in a bar. He then vows to fall in love with the first woman who walks in. A drug dealer, who has a penchant for sunglasses and raincoat, becomes the object of Cop 223's affections after she walks into the bar. Cop 663 is dumped by an air-hostess but unbeknown to him, Faye, a girl at the Midnight Express café which he frequents, develops a serious crush on him. Faye goes to Cop 663's apartment in secret and does some "housekeeping", replacing certain things in the house in order to convey a message that she is in love with Cop 663.

Fallen Angels is also a film with two stories, loosely linked together. Chi-ming is a contract killer who works with a female agent who arranges his assignments. The agent soon becomes obsessed with Chi-ming. Along the way, Chi-ming also rekindles a relationship with Baby, an ex-girlfriend. The second story is about He Qiwu, a mute boy who breaks into establishments at night "to be his own boss". One night, Qiwu meets Charlie, a woman who turns to Qiwu for comfort after she is dumped by her boyfriend. Qiwu falls in love with Charlie, but eventually is rejected.

Lastly, Happy Together is about two gay Hong Kong lovers in Argentina. Ho and Lai embark on a roller coaster relationship of break-ups and make-ups. Lai also befriends a co-worker, Chang, in order to forget about Ho. The film fleshes out the complicated relationships of the three men, and eventually the film ends when all three men realise the difficulty in maintaining a relationship and choose therefore to remain alone. The alienation comes when all three men feel ostracised by a conservative Asian society, which frowns upon a gay lifestyle. For example, Ho has trouble connecting with his father, and thus has run away to Argentina. 
Let's look at how the theme of love and relationships is treated in Wong's films. The relationships will include those between lovers, friends and family members. Many of Wong's characters are constantly looking for someone to love and to be loved by in return. They seek to be understood and to communicate their feelings. Some of the characters have very insecure and fragile selves, while some use idiosyncratic behaviour as a means to communicate, to tell how and what they feel. But the characters are so isolated in their urban living that they lose the sense of how to love another person; as Chiao Hsiung-ping observes, "images of emptiness, the dreary relationships among city people, loneliness and the melancholy help us to enter effortlessly into the empty and deserted souls of the characters."(1)

Most of them retreat into the worlds which they have built for themselves, resulting in others around them being emotionally affected and devastated. Love is a risk into which many of the characters are not willing to venture. Even though some may take the gamble, the situations tend to yield no positive returns. The relationships almost always turn out to be disappointing and the characters end up hurting more and feeling even more alone than ever. Wong comments that his films are about the fact that "a lot of city people have a lot of emotions but sometimes they can't find the people to express them to... Nearly all the characters are hopelessly romantic."(2)

The title Happy Together speaks with much irony about the relationship between Lai and Ho. Ho walks out on Lai frequently and Lai, being tender-hearted, takes Ho back whenever Ho begs for a chance by asking, "Let's start over." After staying put for a while, the flighty Ho soon seeks other people for companionship, leaving Lai high and dry. Ho cannot commit to Lai, even though Lai treats him with the most tender care and utmost patience. Lai accompanies Ho on freezing evening walks, cooks for him even when he is running a high fever, and goes out in the middle of the night to buy cigarettes for him. After Ho is beaten up by a lover, Lai takes Ho in willingly and nurses him back to health. And at the expense of his job, Lai takes revenge on Ho's abusive former boyfriend.

Lai, in a voice-over, remarks that his happiest moments are when Ho is injured and recuperating. Lai watches as Ho sleeps and is happy. When Ho is out of Lai's life, Lai is moody and sullen at work. He loses his temper when he is asked to help a group of tourists take a photograph. But when Ho comes back, Lai is cheerful at work. When another group of tourists needs a group photograph, Lai is patient and jovial, just like Faye in Chungking Express; she too becomes more jovial at work when Cop 663 finally realises her love for him. Lai looks at his watch constantly to check how much longer he needs to work before he can get back home to Ho. Lai calls Ho to see if he has eaten. Chang, Lai's sexually ambivalent colleague, remarks that he can hear Lai's lovey-dovey phone conversation. Chang's eavesdropping confirms that Lai is indeed talking to a lover.

Chang seems to hold some affection for Lai, but this is never realised in the film. The relationship/friendship progresses via football games, drinking sessions and chatting while working in the kitchen. Chang rebuffs a female colleague's advances, telling Lai that he hates the sound of her voice, as he prefers "women's voices to be low and deep. Actually it depends." By saying that it depends, does Chang mean he may prefer men's voices? Chang goes on to ask Lai what sort of voices he prefers and Lai replies that it does not matter, as long as you like that person. Chang knows that Lai is gay as he has picked up Lai's phone call and realises that Lai's lover's voice is actually male.

Chang grabs Lai during football matches and Wong seems to suggest something sexual about Chang's behaviour. When Chang takes a drunken Lai home, removes Lai's pants, stands and looks at him, Lai (and the audience) waits in anticipation as to what Chang is going to do next, as Lai is, in every sense of the word, vulnerable, but Chang closes the door and leaves. Opportunities can become disappointments. In Chungking Express, Cop 223 and the drug dealer spend a chaste night together in the hotel room. Cop 663 and Faye fall asleep next to one another, in Cop 663's house. David Bordwell in Planet Hong Kong comments:

If love is a soliloquy and a dream, it is also devotion: as Faye will spruce up 663's apartment, 223 dutifully wipes off the blonde's shoes while she sleeps... Both men will be abandoned once more, but each is rewarded with a teasing sign of affection. The blonde leaves a birthday message on 223's pager, while Faye dodges a date with 663 but a year later gives him hope by filling out a new boarding pass on a fresh napkin. ${ }^{(3)}$ 
Just as Chang leaves, Faye tells Cop 663 that her next trip away may be for a long time. The drug dealer leaves Hong Kong on the first flight out after killing her Caucasian boyfriend, never to be seen again by 223 or the audience.

Eventually the complicated "love triangle" in Happy Together comes to an end when Ho walks out once again, Chang leaves to go travelling and Lai decides to return to Hong Kong: "Individuals are alone, orphaned, unfit for love, unable to exert the slightest influence on reality (always somewhere else out of reach)."(4)

City people are unable to articulate their innermost feelings. They transfer their affections to objects and technology, which come to represent the characters' emotions. In Chungking Express, Cop 663 blames fish and chips for his break-up. He thinks the choice he has offered his girlfriend is the reason she needs to see if there are any better boyfriends than Cop 663. Cop 663 thinks that he should have stuck with chef's salad. Cop 663 soon begins to "console" his household objects, after his air-hostess girlfriend leaves him. He chides the soap for being too thin, the dish cloth for crying incessantly and the soft toys for being moody and sullen. After being dumped again, this time by Faye, Cop 663 starts talking to his beer bottle.

The love of Cop 663 and his air-hostess may not be based on true feelings, but rather on outward appearance. At a chance encounter after the break-up, 663 bumps into his old flame at the convenience store. Both remark that they prefer to see one another in their respective uniforms. As for Faye and Cop 663, both like the new image of one another. Faye likes 663 in civilian clothes, not his usual no-nonsense police image; and Cop 663 comments that Faye looks nice in her air-hostess uniform. Characters are more in love with the images projected than with the actual characters themselves. The agent in Fallen Angels is in love with Chi-ming's mysterious nature and Chi-ming fuels the feeling by leaving clues about where he goes and what he does. The agent also admits that she may not want to get too "close" to a person, as it can get boring. Qiwu's hair begins to turn blonde as his love for Charlie grows. Charlie thinks that the local football team lost to the Italian team because the latter has taller and blonde players; this is parallelled to her losing Johnny to Blondie.

Cop 223 eats up the thirty cans of expired pineapples as an acknowledgement that his relationship with May is over and she is not coming back. Pineapples are May's favourite food. In order to prevent himself from being hurt again, Cop 223 asks the drug dealer in four different languages whether she likes to eat pineapples. 223 hates the fact that May treats him like canned pineapples, tagged with an expiry date. Like the convenience store employee and the beggar, May likes "things" which are "fresh". 223 is disappointed that everything has an expiry date. Ironically, Qiwu in Fallen Angels is hoping for Charlie's love for her ex-boyfriend to expire quickly, but it does not. Hence Qiwu's optimism and belief about everything having an expiry date are all unfounded. The drug dealer hides behind a pair of sunglasses so that people will not know how vulnerable and insecure she is, or that she has been crying. The drug dealer also believes that people can be fickle too. Someone may like pineapples one day and not the next. This philosophy proves prophetic in the next scene as her Caucasian boyfriend kisses another woman passionately. For the Caucasian boyfriend, emotions are defined by a blonde wig. He will "love" any woman who wears a blonde wig.

Cop 223 uses the telephone to establish an emotional connection with May by calling her family to talk to them. He realises the love is finally over when an unfamiliar male voice answers the phone, and May has only sisters. After that, 223 starts to call up all the girls he knows, even calling up a woman who had attended fourth-grade with him. He does this in hope that he is still remembered by his other girlfriends, even if May has moved on and forgotten him. Cop 223 feels a great need to be remembered. Qiwu, in Fallen Angels, likens himself to a shop to which he has unknowingly let Charlie run, and notes that shops have "feelings". Qiwu does not know how long Charlie will stay "in the shop", but he hopes that it is as long as possible.

In Happy Together, before Chang leaves to go travelling, he asks Lai to say something into a tape recorder. Chang does not like to take photographs as he believes feelings are conveyed better verbally. When Lai tries to speak into the recorder, he starts to cry. Lai's pain and anguish are taped, but he restrains himself from breaking down further. The recording soaks up Lai's painful memories of Ho, which Lai has never expressed. Chang promises to "leave" Lai's recording of pain at the End of the World and then Lai will be freed of the pain. (In In the Mood for Love, the male protagonist speaks into a hole in the ruins of Angkor Wat and then seals the hole, so that the message again which has been unuttered will forever remain in 
the hole. The speaker will be freed of the emotional pain. Ironically, Lai and the reporter are both played by the same actor, Tong Leung.) In Days of Being Wild, Tide places his hopes in getting to know Lizhen further by standing and waiting at the phone booth on his beat, hoping that she will call. Lizhen hates the notion of time, watches and clocks as they constantly remind her of Yuddy. Watches and clocks represent fate's inevitability. The need for a relationship and communication usually comes to us from characters' voice-overs, just like a taped recording.

Loving someone does not equal blind possessiveness, as shown by the following example. When Ho is injured in Happy Together, Lai remarks that those are his happiest days. Lai even goes to the extent of wishing that Ho would not get better so soon. The injured Ho has to depend on Lai, as Lai feeds and cleans him. Lai keeps Ho's passport and refuses to return it to him. Maybe Lai brings Ho to Buenos Aires so that he can have him all to himself, like a prisoner. Being in a strange and hostile foreign environment, both of them will inevitably depend on each other. Lai eventually reaches the Iguazu Falls, but he is alone, unlike the picture on the lamp with two people looking at the Falls. Lai stands there as the water splashes onto his face and smiles, feeling triumphant that he is finally seeing the Falls and that he has broken away from the destructive relationship. Lai may also realise that he cannot successfully possess Ho and hence decides to move on.

In Days of Being Wild, Yuddy does not allow any one woman to possess him. He tells Tide and Lizhen that he knows who he truly loves only towards the very end. After Lizhen leaves Yuddy, because he is a person who does not like the idea of marriage, Yuddy has no qualms taking on another girlfriend, Mimi. Mimi also wants to possess Yuddy exclusively, but as Lizhen tells her, Yuddy treats all women alike. He does not even allow his aunt/foster mother to possess him, even if the possession is to shield him from his biological mother's rejection. By trying to possess Yuddy, all the women lose him.

Wong's characters fear the heavy price which love demands. It can mean disappointments, more pain and rejection. Faye, in Chungking Express, decides to see the real California first, before getting together with Cop 663. The relationship between the drug dealer and Cop 223 never takes off. Chi-ming acknowledges that the agent has become a part of him and his routine but he does not reciprocate her love. He tells the agent to Forget Him, using a song on the jukebox. Eventually some characters decide to be alone in order to shield themselves from the negativity which love can bring. Chiao writes that "Wong Kar-wai's characters are stereotyped individuals of the 90s. They long for love and they fear love, they want more intimate contact but refuse it, in the end they build their utopia on a certain utterly visionary imagination and expectation." (18) Lalanne also notes that "nothing, it seems, is more fearsome than feelings, and nothing is more destructive than a bad feeling."(24)

Love, in Wong's films, is realised only when one loses it. For the characters, falling or being in love is equated to sleepwalking or drifting clouds in the sky (the last being a constant motif in Wong's films). One can never be sure of what love is. In Happy Together, Ho clutches and cries pitifully into the blanket which Lai used, all alone in Lai's former rented room. Now, Lai is gone and Ho only then realises that he has rebuffed Lai's continuous efforts in loving him: "The film suggests that the tension in the relationship is due to a conflict between the two men's differing attitudes regarding commitment: Lai appears to want monogamy while Ho is sexually open..."(5)

Love in the urban environment can also be about settling for second best. Rather than have nothing, characters make do. Lizhen, in Days of Being Wild, begs Yuddy for a second chance and does not mind not being married. Zeb tells Mimi to come and look for him if she fails to find Yuddy in the Philippines. Yuddy's aunt/foster mother hangs around younger men even if they are only after her money. Mimi will earn money to support Yuddy if it makes the two of them happy. In Chungking Express, Cop 663 will follow wherever Faye puts down on the "boarding pass" as destination. Cop 223 will simply live with the memory of a stranger telling him "Happy Birthday". The agent in Fallen Angels masturbates on Chi-ming's bed to feel close to him. Qiwu follows Charlie around like a love-sick puppy, even though Charlie still has feelings for her ex-boyfriend and she is only "borrowing" his shoulder for comfort (this is parallelled to Lizhen in Days of Being Wild, who seeks solace in Tide's company in order to forget Yuddy). Baby agrees to spend just one night with Chi-ming and hopes that he will love her the next day.

Love is usually one-sided. Blondie and the agent love Chi-ming, Qiwu loves Charlie just as Charlie loves 
her ex-boyfriend. It is a one-sided transaction, just as Qiwu forces unwilling "customers" to use his laundry service, to get a haircut, to buy meat or vegetables, to eat ice-cream. Eventually the agent and Qiwu settle for a ride together through the Cross-Island Tunnel. Ackbar Abbas in Hong Kong explains:

All affective binds are double-binds. As a result, no story has a happy conclusion and everybody comes off second best. Love then is either entirely selfish and exploitative (Yuddy and his foster mother); or it is a boringly predictable sequence of friendship, sex, cohabitation and marriage to be avoided at all costs (Yuddy and Lai Jun/Lizhen); or it is a struggle for domination, a competition about who cares less (Yuddy and Mimi); or it does not even arrive at the stage of being a relationship (Lai Jun/Lizhen and the policeman; Yuddy's best friend and Mimi).(6)

Wong also explores the issue of family relationships, although they do not take precedence over romantic relationships. In Happy Together, Lai calls his father but hangs up when he cannot find the right words to say. Lai has taken money from his former workplace before leaving Hong Kong and the employer actually is his father's good friend. Then Lai decides to send his father a Christmas card. As he writes in the card, the message soon becomes a letter as Lai has many things he wants to tell his father but did not when he was in Hong Kong. Just as he has asked Ho, he asks his father for another chance. Lai does not know how his father will react but nevertheless posts the card. When Lai stops over in Taipei en route to Hong Kong, he visits the night market and eats at the food stall run by Chang's family. Lai sees Chang's photos at the stall. He finally understands why Chang can travel extensively, as Chang has a loving family he can return to when he is done travelling. Chang has a family relationship which Lai envies. The closeness which Lai can detect between Chang and his family is true. When Chang is at the "End of the World", the last lighthouse at the southern tip of America, Chang comments that he is no doubt far from his family, but at that moment and place where tranquillity prevails, Chang feels very close to his family then and there: "Though I am faraway from them, for one moment I feel very close."

In Days of Being Wild, Yuddy longs for a real family. He fails to see that his aunt/foster mother is the only family he has and needs. When he reaches the Philippines, he realises his biological mother does not want him and refuses even to see him. Yuddy's aunt, in not revealing Yuddy's biological mother's whereabouts, wants to protect him from the rejection. She even offers an opportunity for Yuddy to follow her to the US, but things go horribly wrong when Yuddy tries to get a passport to go to America. Yuddy, unfortunately, is never reunited with his aunt/foster mother.

Chi-ming, in Fallen Angels, also yearns for a real family. He carries a photograph of a black woman and a young boy and he tells those who ask, that the people in the photograph are his wife and son. Chi-ming needs to create a sense of belonging for himself via the "fake" family photograph, but as he gets injured frequently, Chi-ming realises he needs to change his lifestyle. He wants to settle down to a proper job, like the ex-classmate whom he meets on the bus, and begins to make inquiries about running a business. Chi-ming also wants a companion. He rejects the agent because she is not a person with whom he could spend his life; Chi-ming wants a normal family life.

Among Wong's films, the one in which bittersweet family relationships are most explicitly portrayed is Fallen Angels. A Japanese father apologises in a video for not being with his son on his birthday, and a family of three generations is driven around Hong Kong in the middle of the night in an ice-cream truck, enjoying themselves. However, the best family relationship is the one between Qiwu and his father, although it is also quite short-lived as Qiwu's father dies. Qiwu's father is very protective of Qiwu and does not force his son to seek a normal way of life, even though Qiwu has been to prison a few times because of burglary. Qiwu and his father have a relationship which does not require any verbal communication. Qiwu is mute after eating a can of expired pineapples at the age of five and after his mother was killed in an ice-cream truck accident, his father became quiet and did not enjoy talking.

Qiwu films his father working and at leisure, and compiles all these moments into a video. Although the video shows Qiwu being yelled at by his father, there are also tender moments. For example, Qiwu and his father sleep peacefully in their dingy room, and Qiwu's father smiles when he is cooking. On his sixtieth birthday, Qiwu's father wakes up in the middle of the night and watches the video. While he watches, he laughs and is pleased with it. After the death of his father, Qiwu takes only the video when he has to leave Chungking Mansions, where his father was a caretaker. 
The city environment does damage to its inhabitants. It puts obstacles in the way of characters when they want to love and be loved in return. The city mocks their efforts to find true love and companionship. In Chungking Express, relationships seem to be based on bumping into strangers due to the crowdedness of the city. Cop 223 and the drug dealer meander around, as if looking for love and comfort in the most unexpected places. As they run through the narrow alleyways, the audience cannot see clearly amidst the blurry camera work. In Fallen Angels, love is chaotic like the fights in restaurants, and love is transient and is also quickly over, like the subway train running on the tracks. Wong's characters "live in the world's most crowded cities but are utterly alone. It's as if the bustling, vibrant, neon-slicked streets are conspiring against them, teasing them with chance encounters and fleeting love affairs that are doomed to fail." (7)

Wong's films make a study of relationships in the urban environment. The basis of many of the relationships is one based on an exchange of goods and services.

Cosmopolitan life has eroded the characters' ability to feel and emotions are transposed to objects and services. Qiwu in Fallen Angels ambushes unwary passers-by to buy his products or to use his services. For instance, there is an unfortunate customer who always bumps into Qiwu and is forced to have a haircut or even to eat tubs of ice-cream, to the extent that his whole family is squeezed into a small van, all eating ice-cream. Qiwu has a need to reach out and communicate his feelings, but cannot do so conventionally as he is mute and does not have much education. All in all, Wong's characters have a blind devotion to the past and fail to see new opportunities. They never learn from their mistakes and sometimes hurt other people in the process. Lizhen does not realise she may actually be able to cultivate a positive relationship with Tide, if she were not so fixated on Yuddy. While some characters do meet tragic ends due to their own angst, Wong does provide a glimmer of hope to characters who seemingly can move on with their lives, even though the action they take can be still considered as warped.

Wong's films tell us about the problems of forming relationships in the urban environment. His films may not have clear closures, but they present to the audience a stylistic reflection of the everyday environment. There are no solutions offered in the films, but they do offer us an understanding that we are not alone in this confused world.

"Do you know what the most important thing is in my life?"

"Your son?"

"I thought so too. But as he grows up, I know he'll be leaving me one day. Nothing's important to me now. I thought the words "I love you" really mattered. I thought they meant a lifetime commitment. But looking back, nothing matters... because everything changes. I thought I was the winner, until one day I looked into the mirror and saw the face of a loser. I failed to have the person I loved most to be with me in my best years. How wonderful it would be if we could forget the past..." (The conversation between Huang Yao-shi and Ou-yang Feng's lover in Ashes of Time)

\section{Notes}

1. Chiao, Cinemaya, 18.

2. Quoted in Bordwell, 283-4.

3. Bordwell, 284. 4. Lalanne, 27. 5. Lippe, 58. 6. Abbas, 55.

7. Stefan Hammond, Hollywood East (Chicago: Contemporary Books, 2000), 46.

\section{References}

\section{Bibliography}

Abbas, Ackbar. Hong Kong. Minneapolis: University of Minnesota Press, 1997. 
Abrams, M. H. A Glossary of Literary Terms. Fort Worth: Harcourt Brace Jovanovich College Publishers, 1993.

Belton, John ed. Movies and Mass Culture. Piscataway, NJ: Rutgers Univ. Press, 1996.

Bordwell, David. Planet Hong Kong. Boston: Harvard University Press, 2000.

Brooker, Peter ed. Postmodern After-Images. London: Arnold, 1997.

Chiao Hsiung-ping, Peggy. "Happy Together - Hong Kong's Absence". Cinemaya. 38 (1997): 17-21.

Connor, Steven. Postmodernist Culture. Oxford: Basil Blackwell, 1989.

Degli-Esposti, Cristina ed. Postmodernism in the Cinema. New York: Berghahn, 1998.

Eagleton, Terry. The Illusion of Postmodernism. Oxford: Blackwell, 1996.

Hammond, Stefan. Hollywood East. Chicago: Contemporary Books, 2000.

Hassan, Ihab. The Postmodern Turn. Ohio: Ohio State University Press, 1987.

Havis, Richard James. "One Entrance, Many Exits". Cinemaya. 38 (1997): 15-16.

Kitano, Takeshi. "An Interview with Wong Kar-wai". Brutus. August, 1997: 6-9

Lalanne, Jean-Marc et al. Wong Kar-wai. Paris: Editions Dis Voir, 1999.

Lippe, Richard. "Gay Movies, East and West". Cineaction. 45 (Feb 1998): 47-59.

Lodge, David, ed. Modern Criticism and Theory. New York: Longman Inc., 1988.

Lucy, Niall. Postmodern Literary Theory. Oxford: Blackwell, 1997.

McRobbie, Angela. Postmodernism and Pop Culture. London: Routledge, 1994.

Morawski, Stefan. The Troubles with Postmodernism. London: Routledge, 1996.

Samp, Madan. Post-structuralism and Postmodernism. Brighton and New York: Harvester Wheatsheaf, 1988.

Teo, Stephen. Hong Kong Cinema. London: bfi Publishing, 1997.

www.cinema_nutrition.com/wongkarwai/

\section{Films}

Wong, Kar Wai, As Tears Go By, Hong Kong: Scholar Productions, 1998. Ashes of Time, Hong Kong: Scholar Productions, 1994. . Chungking Express, Hong Kong: Jet Tone Production Co., 1996.

. Days of Being Wild, Hong Kong: In-Gear Films, 1991.

. Fallen Angels, Hong Kong: Jet Tone Production Co., 1995.

. Happy Together, Hong Kong: Jet Tone Production Co., 1997.

. In the Mood for Love, Hong Kong: Jet Tone Production Co., 2000.

\section{Author Information}

Ethel CHONG has completed her MA with the National University of Singapore in Singapore. Her research work concentrates particularly on Hong Kong Cinema and Wong Kar-wai. 